\title{
Media and Online Analysis of Settlements from Saint Ladislaus Memorial Road
}

\author{
István BENEDEK \\ Doctoral School of Communication, Public Relations and Advertising \\ Babeș-Bolyai University, Cluj-Napoca \\ E-mail: benedek.istvan@fspac.ro
}

\begin{abstract}
The primary goal of the current paper is to emphasize the most important natural and cultural values of 30 analyzed settlements, included in the path of the Saint Ladislaus memorial road. In order to define these core values, the study applies several research methods, previously described in the literature of place branding, including the media- and the online presence analysis of the settlements. The first part of the paper presents the idea behind the Saint Ladislaus memorial road and establishes the theoretical foundation for the current study. The second part contains a brief description of all the settlements included in the current research. The third part describes the research methodology and presents the results of the media- and online presence analysis. The final part of the paper formulates the conclusions and indicates some starting points for future research.
\end{abstract}

Keywords: place branding; destination branding; media analysis; online presence.

\section{Introduction}

The aim of the project is to create a memorial road that connects those settlements in the Carpathian Basin that can be related to Saint Ladislaus. As king of Hungary Saint Ladislaus reigned between 1077 and 1095 and this period had a great importance in Hungary's history because Saint Ladislaus in fact finished the 


\section{References}

1. Hankinson, G. (2007). The Management of Destination Brands: Five Guiding Principles Based on Recent Developments in Corporate Branding Theory. Journal of Brand Management, 14(3), 240-254.

2. Kádár, M. (2014). The process of Settlement Branding. Case studies on City Branding in Transylvania. Transylvanian Review of Administrative Sciences. [Special Issue], 55-69.

3. Kádár, M. (2016). Media Image Analysis of the Western Region of Sălaj County. Journal of Media Research, 9, 3(26), 78-95.

4. Kavaratzis, M. (2004). From city marketing to city branding: Towards a theoretical framework for developing city brands. Place Branding, 1(1), 58-73.

5. Kotler, P. \& Gertner, D. (2002). Country as a brand, product and beyond: A place marketing and brand management perspective. Journal of Brand Management, 9(45), 249-261.

6. Lee, I. \& Arcodia, C. (2011). The role of regional food festivals for destination branding. International Journal of Tourism Research, 13(4), 355-367. 
7. Llinares, C., Page, A. \& Llinares, J. (2013). An approach to defining strategies for improving city perception: Case study of Valencia, Spain. Cities, 35, 78-88.

8. Papp-Váry, Á. (2011). Hogyan lesz a településból márka? A városmárkázás alapjai. [URL: http://www.papp-vary.hu/varosmarkazas/Hogyan_lesz_telepulesbol_marka.pdf], accessed on April 28, 2017.

9. Qu, H., Hyunjung Kim, L. \& Hyunjung, Im H. (2011). A model of destination branding: Integrating the concepts of the branding and destination image. Tourism Management, 32, 465-476.

10. Ryan, J. \& Silvanto, S. (2009). The World Heritage List: The making and management of a brand. Place Branding and Public Diplomacy, 5(4), 290-300.

11. Seymour, T., Frantsvog, D. \& Kumar, S. (2011). History of Search Engines. International Journal of Management $\mathcal{E}$ Information Systems, 15(4), 47-58.

12. Statista (2017). Worldwide desktop market share of leading search engines [www.statista. com/statistics/216573/worldwide-market-share-of-search-engines/], accessed on April 25, 2017.

13. Tőkés, Gy. (2011). A kutatás módszertana a kommunikációtudományokban. Kolozsvár: Scientia.

14. Van Deursen, A., Van Dijk, J. (2009). Using the Internet: Skill related problems in users online behavior. Interact Comput, 21(5-6), 393-402.

15. Zenker, S., Beckmann, S.C. (2013). My place is not your place - different place brand knowledge by different target groups. Journal of Place Management and Development, 6(1), 6-17. 